\title{
Physiological Studies on the Outgrowth of the Epicotyl in Stizolobium hassjoo II. Its IAA Metabolim with Special Reference to the Activity in IAA Destruction
}

\author{
by Mitsuhiko Satô,* Atsushi Komamine* \\ and Masami Shimokoriyama*
}

\begin{abstract}
Received May 1, 1963
In the previous paper ${ }^{1)}$ were reported some characteristics of the outgrowth which developed a few days after the epicotyl of Stizolobium hassjoo was cut. The plant tumors such as crown gall ${ }^{2-4)}$, genetic tumor ${ }^{5)}$ and habituated tissue ${ }^{6 /}$ have been known to be capable of growing in vitro without any exogenous supply of indoleacetic acid (IAA), and it has been reported in some crown galls that their IAA content was maintained on a relatively high level ${ }^{7,8)}$. Also the outgrowth of $S$. hassjoo could be grown, though to a certain extent, on a culture medium without any addition of IAA. It may be possible, therefore, to suppose that there might be something common among these plant tumors and our outgrowth. In crown gall, the way in which its IAA content is maintained on a relatively high level has been connected with an increased rate of IAA synthesis ${ }^{8)}$ and/or with a decreased rate of IAA destruction ${ }^{9)}$. To examine the IAA content and the IAA destructive activity in the outgrowth of $S$. hassjoo is the main purpose of this report.
\end{abstract}

\section{Material and Methods}

Material: The material used in this work was the same as that in the previous paper ${ }^{11}$.

Estimation of IAA: Free IAA was extracted three times with cold ether $(600$ $\mathrm{ml}$ in total) from $40 \mathrm{~g}$ outgrowth and $40 \mathrm{~g}$ epicotyl, and each combined extract was concentrated in vacuo, being chromatographed with a solvent of iso-propanol-ammoniawater $(10: 1: 1, \mathrm{v} / \mathrm{v})$. The chromatogram was divided into twelve bands and growth promoting activity in each band was estimated by ordinary Avena straight-growth test. The chromatographic behavior of the main growth substance was compared with that of authentic IAA by using two solvents, $i$ so-propanol-ammonia-water $(10: 1: 1$, $\mathrm{v} / \mathrm{v})$ and $70 \%$ ethanol.

Determination of IAA destructive activity: Determination of IAA destructive activity of the outgrowth and the three parts of epicotyl, that is, (I), (II) and (V)** was conducted with slice, homogenate and crude enzyme.

Bores of $5 \mathrm{~mm}$ diameter were taken from the outgrowth and cut transversely into discs approximately $0.5 \mathrm{~mm}$ thick. In epicotyl, eight slices of about the same

* Department of Botany, Faculty of Science, University of Tokyo, Hongo, Tokyo, Japan.

** For the sake of convenience, some abbreviations are used in this report. The terms part (l), (II) and (V) mean the segment of $1 \mathrm{~cm}$ length obtained from epicotyls, (I) corresponding to the segment from the tip to $1 \mathrm{~cm}$ below it, (II) to that between 1 and $2 \mathrm{~cm}$ below the tip, and so on. The term $(\mathrm{O})$ represents the outgrowth. On the other hand, cut surfaces (I) and (V) designate those at positions 1 and $5 \mathrm{~cm}$ below the tip, respectively. 
thickness as that of the outgrowth discs were cut from the central region of each segment. The slices were immediately washed two times with a buffer, and fresh weight per slice was determined with a part of samples. Phosphate buffer $\left(10^{-2} \mathrm{M}\right)$ of $\mathrm{pH} 6.0$ was used throughout the experiments on IAA destruction.

Homogenate was prepared by crushing the frozen material in the cold buffer and by pressing the resultant brei through a fine silk. The final volume of homogenate obtained from $1 \mathrm{~g}$ fresh material was adjusted to $2 \mathrm{~m} l$ with the buffer.

The homogenate prepared as mentioned above was centrifuged at $5000 \mathrm{~g}$ for ten minutes, and by adding to the resultant supernatant three times its volume of acetone previously cooled to about $-15^{\circ}$, precipitate was obtained. It was dissolved in the buffer (precipitate from $2.2 \mathrm{~g}$ fresh material in $1 \mathrm{ml}$ buffer) and the solution was used as crude enzyme.

One $\mathrm{m} l$ buffer solution containing about $300 \mathrm{mg}$ fresh slices, $1 \mathrm{ml}$ homogenate or $2.0 \mathrm{~m} l$ crude enzyme solution was incubated with $2 \mathrm{ml} 10^{-4} \mathrm{M}$ IAA for $30 \mathrm{~min}$. at $30^{\circ}$. The reaction vessels were oscillated 100 times a minute. Since through a preliminary experiment the crude enzyme solutions were found to show no IAA destructive activity without cofactors, $0.2 \mathrm{~m} l 10^{-3} \mathrm{M}$ dichlorophenol and $0.2 \mathrm{~m} l \cdot 10^{-4} \mathrm{M} \mathrm{MnCl}_{2}{ }^{10}$ ) were added to the reaction mixture. After the reaction, $\mathrm{pH}$ of the solutions was adjusted to 3 with $1 \mathrm{ml}$ of $0.1 \mathrm{M}$ citrate phosphate buffer ( $\mathrm{pH} 3: 0$ ), and the remaining IAA was extracted five times with $30 \mathrm{ml}$ ether in total. The quantity of IAA was estimated according to the method of Tang and Bonner ${ }^{11}$.

\section{Results and Discussion}

1) Promoting effect of IAA on the outgrowth formation: It was shown in the previous paper ${ }^{1)}$ that the outgrowth developed not from part (I) in which an active auxin production might be expected, but from the lower parts which might be regarded not to be high in auxin content. This seems to suggest that a high endogenous IAA content might be inhibitory to the outgrowth formation. In the following experiments, however, IAA was proved to be effective on the development of the outgrowth (Fig. 1).

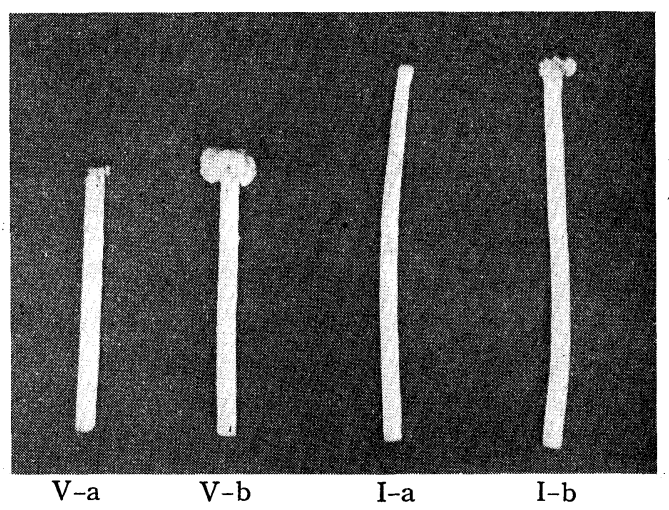

Fig. 1. Promoting effect of IAA on the formation of the outgrowth. I-a, treated the cut surface (I) with lanolin paste without IAA; I-b- with IAA; V-a, treated the cut surface (V) with lanolin paste without IAA; V-b,_-with IAA. Photographed 5 days after the treatment. 
On the cut surface (I) and (V) of epicotyls was smeared lanolin paste containing IAA $\left(0.4 \mathrm{~m} l \quad 10^{-4} \mathrm{M}\right.$ IAA was mixed with $1 \mathrm{~g}$ lanolin) or paste containing distilled water $(0.4 \mathrm{~m} l$ distilled water mixed with $1 \mathrm{~g}$ lanolin). Although in part $(\mathrm{V})$ the outgrowth formation occurred without supplying IAA, it was remarkably accelerated by smearing the IAA-containing lanolin on the cut surface. On the other hand, the formation of the outgrowth on the cut surface (I) was induced only when the cut surface was exogenously supplied with IAA.

As shown above, in part (I) which did not give rise to any outgrowth by cutting, the outgrowth formation was enabled by exogenous application of IAA. This implies that a larger amount of IAA than that expected in the growing area of epicotyl may be necessary for the transformation of the non-outgrowth cells into outgrowth ones. Thus it is probable that in the lower parts of the epicotyl as part (V) a large amount of IAA may be accumulated in the cut region and take a part in the formation of the outgrowth.

It has been reported that IAA applied to plant organs induces the formation of some types of outgrowth. The application of IAA mixed in lanolin (1.5-3\%) promoted the production of outgrowth, for example, in the stem of bean (Phaseolus vul aris) ${ }^{12}$ and tomato ${ }^{13)}$, and the pods of bean ${ }^{12)}$. The outgrowth of this type has been called auxin induced tumor. In the outgrowth induced by the action of Agrobacterium tumefaciens, it was demonstrated that tomato plants inoculated with an attenuated culture of this bacteria (avirulent strain) were capable of forming tumors when supplemented with 1-3\% IAA mixed in lanolin $^{14,15}$. But when tomato was inoculated with a virulent strain of this bacteria and applied with $1 \%$ IAA in lanolin paste, tumor formation was suppressed ${ }^{16)}$. Since the application of virulent strain of $A$. tumefaciens has been reported to bring in the inoculated region a high IAA state ${ }^{17-19}$, the suppressing effect of IAA in the latter case may be attributed to an excess supply of IAA unfavorable for the formation of tumor. In fact, an excess supply of IAA $\left(0.4 \mathrm{~m} l 10^{-2} \mathrm{M}\right.$ IAA in $1 \mathrm{~g}$ lanolin) to the epicotyl of $S$. hassjoo was found to be inhibitive to the formation of the outgrowth both in cut surface (I) and (V).

From the foregoings it is probable that the outgrowth formation may be enabled by provision of a certain amount of IAA.

2) IAA content in the outgrowth: The accelerated formation of the outgrowth by exogenous supply of IAA implies that, during the transformation into outgrowth cells of non-outgrowth ones, an active maintenance of IAA activity may take place in the cut region. If the incipient outgrowth cells might have gotten an ability to produce by themselves a large amount of IAA, the outgrowth cells which have resulted from them would be expected to be high in IAA content.

The diagramatic illustration in Fig. 2 clearly demonstrates the hyperauxinic character of the outgrowth, whose IAA content is estimated considerably higher than that of non-outgrowth epicotyl.

Another support of this aspect came from the observation given in Fig. 3. A high auxin content has been reported to result in the formation of adventitious root, inhibition of lateral bud formation, etc. These were the case with the outgrowth developing epicotyl of $S$. hassjoo. The epicotyl was cut at a position $5 \mathrm{~cm}$ below the tip. The treated plants were divided into two groups, the first being let produce the outgrowth (Fig. 3-A), and the second, in which a layer of 1-2 mm thickness was removed from the cut surface every two or three days so that no outgrowth might be formed (Fig. 3-B). In both groups, a pair of lateral buds which developed from the base of epicotyl was excised. As shown in Fig. 3, further formation of lateral buds 


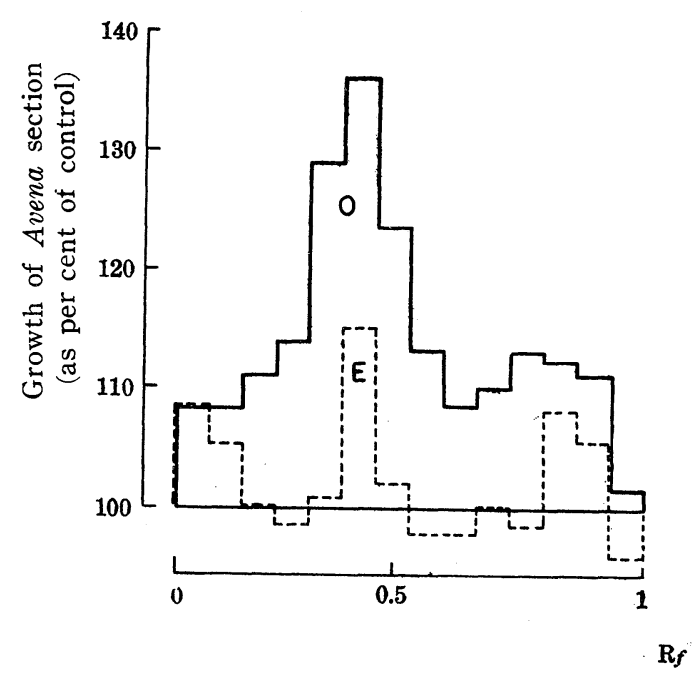

Fig. 2. Histograms showing the growth promoting activity of the extracts obtained from the outgrowth $(\mathrm{O})$ and epicotyl (E). Chromatographed with $i$ so-propanol-ammonia-water (10:1: $1, \mathrm{v} / \mathrm{v})$. Chromatographic behavior of the main growth substance was similar to that of authentic IAA with two solvents.

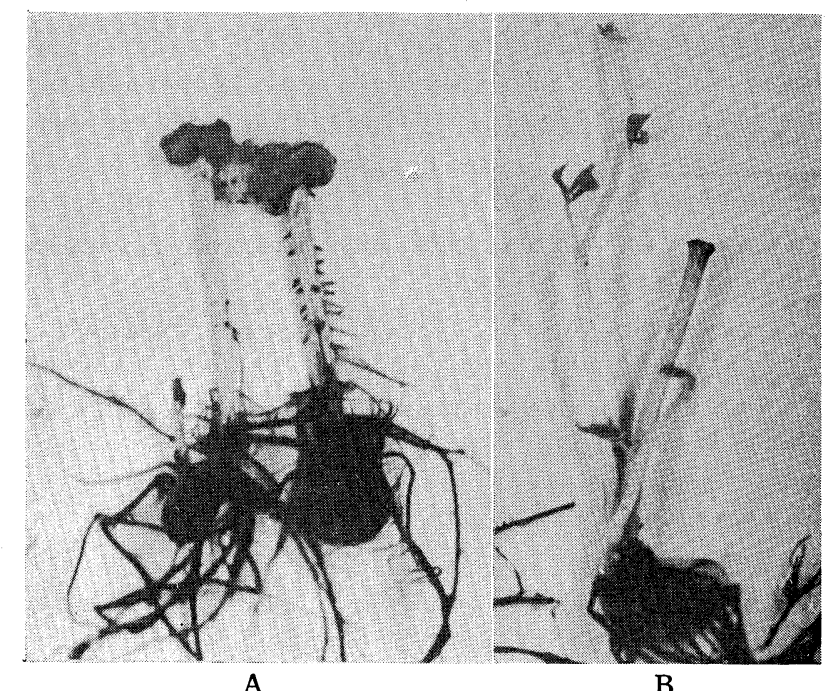

Fig. 3. Another evidence to indicate the hyperauxinity of the outgrowth. In the outgrowth-bearing epicotyl (A), suppression of lateral bud formation and promotion of adventitious root development can be seen as compared with the control bearing no outgrowth (B). Photographed a few days after the epicotyls were cut.

was suppressed in the first group, but not in the second. In addition to this, the formation of adventitious roots could be seen in the former, but not in the latter. 
Hyperauxinity of the tumorous tissue has been well evidenced. In stem of tomato plant inoculated with $A$. tumefaciens, it was found that the auxin content increased with the time after inoculation ${ }^{17-19)}$. The crown galls of Scorzoneral and sunflower ${ }^{8)}$ were reported to contain much more free auxin than comparable nontumorous callus tissue, and a tumorous tissue in potato induced by Synchytrium endobioticum was also found to be high in its free IAA content as compared with nontumorous tissue ${ }^{20)}$. The present outgrowth possesses a property common to other outgrowth in this respect.

3) IAA destruction in the outgrowth: A remarkably high IAA content in the outgrowth, as shown above, made us investigate the way in which IAA content is maintained on such a high level. In crown gall, its high IAA content has been supposed to arise by an increased rate of IAA synthesis and/or by a decreased rate of IAA destruction. In the present study, the activity of IAA destruction in the outgrowth was examined.

In Fig. 4 is shown the destruction of IAA by slices, homogenate and crude enzyme obtained from the outgrowth and the three parts of the epicotyl, (I), (II) and (V). Experiments were run twice.
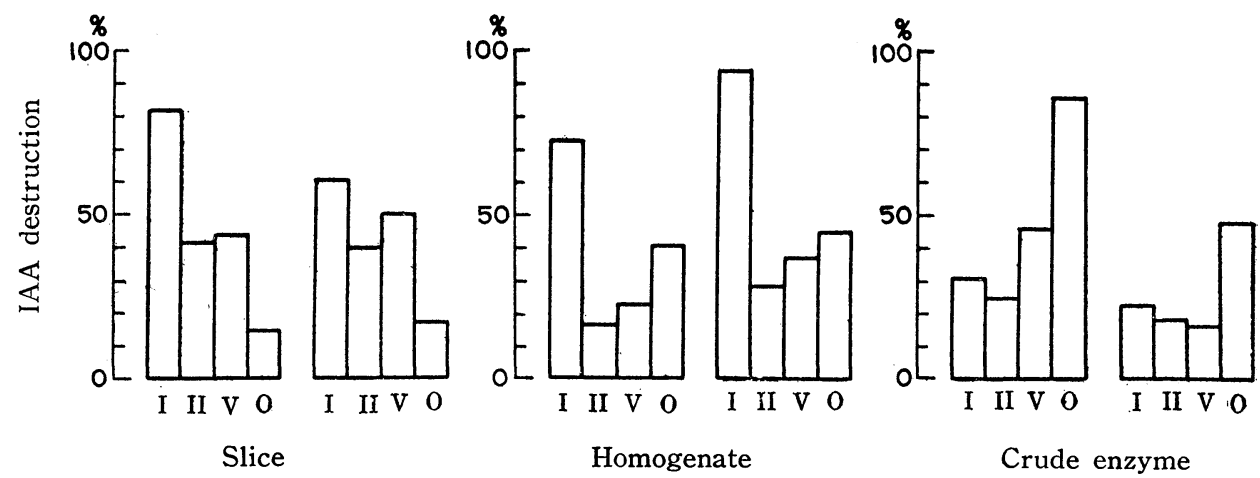

Fig. 4. Histograms indicating the IAA destructive activity of the three parts of epicotyl (I, II, V) and the outgrowth (O) with slice, homogenate and crude enzyme.

Between the IAA destructive activities in (II) and (V), no significant difference can be found. On the other hand, IAA destruction by $(\mathrm{O})$ and $(\mathrm{I})$ is supposed to be done in different manners not only from (II) and (V), but also from each other. In slice, IAA is considerably destroyed by $(\mathrm{I})$, while slightly by $(\mathrm{O})$. In homogenate, alike in slice, IAA destructive activity is higher in (I) than in $(\mathrm{O})$. But IAA destruction by crude enzyme is much stronger in $(\mathrm{O})$ than in (I). These results suggest the presence in (I) of an accelerator and in (O) of an inhibitor of IAA destructive enzyme system. These factors may be supposed to have been in some way decom. posed or removed from homogenate and crude enzyme.

Bitancourt ${ }^{9)}$ suggested that the activity to destroy IAA might be smaller in crown gall than in normal tissue. But in Parthenocissus tricuspidata ${ }^{21)}$, sunflower ${ }^{8)}$ and potato $^{22)}$, no significant difference was found between normal and tumorous tissue in regard to their IAA destructive activity.

In $S$. hassjoo, however, it appears that in intact outgrowth an almost negligible: 
IAA destruction may be carried out, and its IAA content, in part, may be in this way maintained on a high level. This coincides with the suggestion by Bitancourt. The possibility that, as proposed by Henderson and Bonner on the crown gall of sunflower ${ }^{8}$, the increased rate of IAA synthesis might be responsible for the maintenance of high IAA level, will be examined later on.

\section{Summary}

In this report, the outgrowth whose characteristics have already been described is examined for its IAA metabolism with special reference to its IAA destructive activity.

1) The outgrowth formation from the cut surface of the epicotyl was remarkably accelerated by the application of IAA. This was observed not only in the lower parts of epicotyl, but also in the growing area which did not develop any outgrowth when subjected only to cutting. It is suggested that a relatively large amount of IAA may accumulate in the cut region and take a part in the formation of the outgrowth.

2) The outgrowth was found to possess a considerably high amount of IAA as compared with non-outgrowth epicotyl.

3) The maintenance by the outgrowth of such a high level of IAA may be, in part, attributed to the decreased rate of its in vivo IAA destruction.

The authors express their thanks to Dr. Hiroh Shibaoka, Botanical Garden of University of Tokvo, for his kind help in IAA analysis.

\section{References}

1) Komamine, A., Satô, M., and Shimokoriyama, M., Bot. Mag. Tokyo 73: 130 (1963). $\quad$ 2) de Ropp, R. S., Amer. J. Bot. 34: 52 (1947). 3) .Gautheret, R. J., Compt. Rend. l'Acad. Sci. Paris 224: 1728 (1947). 4) —, ibid. 226: 270 (1947). 5) White, P. R., Amer. J. Bot. 26: 59 (1939). 6) Gautheret, R. J., Compt. Rend. Soc. Biol. 140: 169 (1946). 7) Kulescha, Z., and Gautheret, R. J., Compt. Rend. l'Acad. Sci. Paris 227: 292 (1948). 8) Henderson, J. H. M., and Bonner, J., Amer. J. Bot. 39: 444 (1952). 9) Bitancourt, A. A., Mecanismo Genético da Tumorisção nos Vegetais (Segunda Semana de Genética, Piracicaba, São Paulo, Feb. 8, 1949). 10) Hillman, W.S., and Galston, A. W., Physiol. Plant. 9: 230 (1956). 11) Tang, Y.W., and Bonner, J., Arch. Biochem. 13: 11 (1947); Amer. J. Bot. 35: 570 (1948). 12) Hamner, K. C., and Kraus, E. J., Bot. Gaz. 98: 735 (1937). 13) Link, G. K. K., Wilcox, H. W., and Link, A. D., ibid. 98: 816 (1937). 14) Braun, A. C., and Laskaris, T., Proc. U. S. Nat. Acad. Sci. 28: 468 (1942). 15) Klein, R. M., and Link, G.K.K., ibid. 38: 1066 (1952). 16) Terekhova, N. A., Izvestiya Akad. Nauk, USSR 3: 431 (1959). 17) Lock, S. B., Riker, A. J., and Duggar, B. M., Phytopath. 27: 134 (1937). 18) - —, and - J. Agric. Res. 57: 21 (1938). 19) Link, G. K. K., and Eggars, V., Bot. Gaz. 103: 87 (1941). 20) Reingard, T., and Pashkar, S.I., Phiziologia Rasteni, USSR 5: 501 (1958). 21) Lipetz, J., and Galston, A. W., Amer. J. Bot. 46: 193 (1958). 22) Pashkar, S. I., and Reingard, T. A., Dokl. Acad. Nauk, USSR 126: 428 (1959). 
佐 藤 满彦・駒嶺 穆・下郡山正巳: ハッショウマメのめば忞にで

きる一種のカルス (outgrowth) の生理学的研究 II. その IAA

代謝, とくにその IAA 破壊活性

本報では，前報でその性質のいくつかを記載した，ハッショウマメの芽㜔えにできる outgrowth の IAA 代謝，とくにその IAA 破壊活性をしらべた。

1）上胚軸をきっただけでは outgrowth のできない先端部でも，その切口に IAAを与穴ると，outgrowth が形成される。このことから, 上胚軸の下の部分の切ロから outgrowth ができるさいには, 切 った個所に，生長点に期待できるょりも多くのIAA が蓄積し，これが outgrowth の形成に一役買うもの と考完られる。

2) Outgrowth には，上胚軸にくらべていちじるしく多量のIAA がふくまれている.

3) Outgrowth で IAA がこのよ5に高濃度にたもたれる原因の一端は, その in vivoの IAA 破垻能 が上肧軸の諸部分にくらべて低いことにある. (東京大学理学部植物学教室) 